\title{
STANDARD OPERATING PROCEDURE: USE IN NURSING CARE IN HOSPITAL SERVICES
}

\author{
Giselle Patrícia Guerrero \\ Lúcia Marinilza Beccaria² \\ Maria Auxiliadora Trevizan ${ }^{3}$
}

Guerrero GP, Beccaria LM, Trevizan MA. Standard operating procedure: use in nursing care in hospital services. Rev Latino-am Enfermagem 2008 novembro-dezembro; 16(6):966-972.

This is a descriptive and quantitative study, carried out in three hospitals in the Northwest of São Paulo, Brazil. It aimed to verify the existence and use of Standard Operating Procedures (SOP) by nursing teams. SOPS describe each critical and sequential step of a task to ensure its expected result. A total of 261 nursing professionals participated in the study, randomly selected from different units and shifts between August and September 2006. Results indicate that $56.7 \%$ use SOPs only when they have doubts; $54.02 \%$ of the nursing technicians and auxiliaries and $62.86 \%$ of nurses do not believe the procedures are being complied with. These findings indicate the need for continuing training on SOP use and compliance by all professionals, with a view to improving nursing care.

DESCRIPTORS: techniques; nursing care; nursing

\section{PROCEDIMIENTO OPERACIONAL ESTÁNDAR: UTILIZACIÓN EN LA ASISTENCIA DE ENFERMERÍA EN SERVICIOS HOSPITALARIOS}

Se trata de un estudio descriptivo con abordaje cuantitativa, realizado en 3 instituciones hospitalarias en el noroeste del estado de San Pablo, con los objetivos principales de verificar la existencia y la utilización, por el equipo de enfermería, de los Procedimientos Operacionales Estándar (POEs), desarrollados a fin de describir cada paso crítico y secuencial para garantizar el resultado esperado de una tarea. Participaron, de forma aleatoria, 261 profesionales de enfermería de diversas unidades de internación en los distintos turnos, entre los meses de agosto y septiembre de 2006. Se verificó que 56,7\% acceden a los POE solamente cuando tienen dudas; $54,02 \%$ de los técnicos y auxiliares y 62,86\% de los enfermeros no creen en el seguimiento de los POE. Esos valores llevan a reflexionar sobre la necesidad de ofrecer entrenamientos continuos en relación a la utilización y seguimiento de los POE por todos los profesionales, a fin de mejorar la asistencia de enfermería.

DESCRIPTORES: técnica; atención de enfermería; enfermería

\section{PROCEDIMENTO OPERACIONAL PADRÃO: UTILIZAÇÃO NA ASSISTÊNCIA DE ENFERMAGEM EM SERVIÇOS HOSPITALARES}

Trata-se de estudo descritivo com abordagem quantitativa, realizado em 3 instituições hospitalares do noroeste paulista, com os objetivos principais de verificar a existência e a utilização pela equipe de enfermagem dos Procedimentos Operacionais Padrão (POPS), desenvolvido a fim de descrever cada passo crítico e seqüencial para garantir o resultado esperado de uma tarefa. Participaram, aleatoriamente, 261 profissionais de enfermagem em diversas unidades de internação nos distintos turnos, entre os meses agosto e setembro de 2006. Verificouse que 56,7\% acessam o POP somente quando têm dúvidas; 54,02\% dos técnicos e auxiliares e 62,86\% dos enfermeiros não acreditam no seguimento do POP. Esses valores levam à reflexão sobre a necessidade de treinamentos contínuos em relação à utilização e seguimento do POP por todos os profissionais, a fim de melhorar a assistência de enfermagem.

DESCRITORES: técnicas; cuidados de enfermagem; enfermagem

${ }^{1}$ Nursing undergraduate student, at Faculdade de Medicina de São José do Rio Preto, Brazil, e-mail: giguerrero7@yahoo.com.br; ${ }^{2}$ Ph.D., Faculty, Faculdade
de Medicina de São José do Rio Preto, Brasil, e-mail: lucia@famerp.br; ${ }^{3}$ Full Professor, University of Sao Paulo at Ribeirao Preto College of Nursing, WHO de Medicina de São José do Rio Preto, Brasil, e-mail: lucia@famerp.br; ${ }^{3}$ Full Professor, University
Collaborating Centre for Nursing Research Development, Brazil, e-mail: iamendes@eerp.usp.br. 


\section{INTRODUCTION}

The concept and importance of the term standardization have been reported since the Industrial Revolution with the process of replacement of human labor by machines. Standardization of production processes aimed to obtain more uniform products with increased production and service quality ${ }^{(1)}$. The word standard means "what serves as basis or norm for evaluation" and is related to the results one wishes to achieve. In the health area, it relates to care standards, which in turn are related to clients' rights of receiving nursing care according to their needs ${ }^{(2)}$

Concern with the quality of healthcare service is not new and, when clients seek hospital services, they aim to reestablish their health, solve problems and normalize dysfunctions. For clients to enjoy quality services, a management system is needed which acknowledges their needs, establishes standards and attempts to keep up these standards with a view to client satisfaction ${ }^{(3)}$. Quality management can be useful to nursing and contribute to the implementation of new methods and changes necessary for the improvement of care and both team and patient satisfaction ${ }^{(4)}$. The best way to begin standardization is to understand how the whole process occurs and, in this case, a systematic representation is required. An example is the Standard Operating Procedure (SOP), which describes each critical and sequential step one has to perform in a task in order to assure its expected result. In addition to its relation to the technique, standardization is a Greek word and refers to the "disposition with which we do things with the help of a true rule" ${ }^{\prime 3,5)}$.

Technical acts induce repetitive actions, which sometimes are performed by many different hands, with similar results being guaranteed to a certain extent. Nonetheless, technical professionals are different beings, with different talents, feelings and knowledge and, although they act with regularity, due to the work context ${ }^{(5)}$, they do not always produce results that satisfy different people, despite the use of the same means. In the nursing area, SOPs are contained in manuals aimed at clarifying doubts and guiding the execution of actions and should be in agreement with the institution's guidelines and standards, be updated whenever necessary, according to scientific precepts that should be followed by all (physicians, nurses and nursing auxiliaries) in a standardized manner ${ }^{(6)}$.

Well-qualified nurses favor the rationalization of routines, standardization and safer procedures, effective participation in care planning and liberation of more time to interact with the patient. Therefore, it is necessary to follow new trends and participate in the construction of alternatives that meet the challenges of improving the supply of quality care services $^{(3,7)}$. In addition, nurses should exert the role of producers, implementers and supervisors of nursing care actions, contemplating a holistic view of the patient and adopting their own reference framework ${ }^{(8)}$.

The lack of standardized procedures, norms and routines, and the non-utilization of a nursing care method indicate lack of organization of the nursing service, due to different professional conducts. Thus, standards are defined aiming to establish guidelines for the control and continuing improvement of quality. Standardized care refers to detailed guidelines that represent predictable care delivery, prescribed for specific situations, which promotes improvement of organizations' processes and results ${ }^{(8-10)}$.

Additionally, the implementation of systems for the development of nursing care, based on standards and criteria, rests on the precept that care should transcend compliance of medical and administrative orders and specifically meet patients' real needs through knowledge ${ }^{(8)}$ and a holistic perspective. Thus, nursing standards define nurses' field of practice and provide guidance to their performance, plan competences and educational demands ${ }^{(11)}$.

In view of the exposed, the objectives of this study were: to define the profile of nursing professionals, verify the existence of SOPs in hospital units; verify whether they are used by nursing teams; identify the review and updating of this material and check whether there are standard committees at these institutions.

\section{METHOD}

This is a descriptive and quantitative study, where the researcher describes functional relations between variables and identifies basic elements of the collected data, showing the evolution of relations 
between different elements ${ }^{(12)}$. It was carried out in three hospitals with 1,666 nursing workers in the Northeast of São Paulo, Brazil. Four hundred questionnaires were randomly delivered to nursing professionals from different sectors and shifts, though only 261 professionals participated in the study. Thus, the sample was composed of 35 nurses, seven nursing technicians and 219 nursing auxiliaries. Those who did not agree to participate in the study or were either on sick or maternity leave, vacation or had taken time off during the data collection were excluded.

A structured questionnaire based on literature was used, with the following script: identification data (age, gender, marital status, state of origin), professional data (professional category, unit of work, time of work and workload) and data on standardization of techniques (existence of manual or standard operating procedure - SOP, difficulties and benefits of its use, evaluation of frequency of use and compliance by the teams, changes and review of SOPs and communication with the board regarding possible changes). Data collection was carried out between August and September 2006 during the morning, afternoon and night shifts.

The Research Ethics Committee approved the study (Protocol no 2932/2006 and Review no 104/ 2006) and the Free and Informed Consent Term was signed with assurance of interviewees' anonymity, according to Resolution 196/96 by the National Health Council (CNS), in addition to the hospitals' permission, named here $A, B$ and $C$.

Hospital A is a general, large, private, teaching facility with 773 beds and 187 nurses, 72 technicians and 1,169 nursing auxiliaries. A total of 31 nurses, three technicians and 184 nursing auxiliaries participated in the study, who work in 22 inpatient units and different shifts. Hospital B is a general, private, medium size facility with 60 beds and nine nurses, 23 technicians and 82 auxiliaries. Two nurses, three technicians and 17 nursing auxiliaries from six inpatient units and different shifts participated in the study. Hospital $C$ is also a general, private, medium size facility with 86 beds and 13 nurses, one nursing technician and 110 auxiliaries, of whom two nurses, one technician and 18 nursing auxiliaries from seven inpatient units and different shifts participated in the study.
The different units and specialties of the mentioned institutions are: medical and surgical clinic, pediatric, geriatric, hemodialysis, obstetrical center, surgical center, bone marrow transplantation unit, intensive therapy unit (general, neonatal and pediatric), coronary unit, nursery, infectious and parasitic disease unit and emergency.

In the quantitative method ${ }^{(12)}$, data are numerically synthesized and tabulated. In this study, data were synthesized, tabulated and presented in charts and figures.

\section{RESULTS}

The study sample presented $76.63 \%$ of female and $23.37 \%$ of male individuals. The age range varied from 20 to 62 years with prevalence of ages between 20 and 40 years (79.70\%). In terms of marital status: $48.27 \%$ were married, $39.08 \%$ single, $11.88 \%$ divorced and $0.77 \%$ widowed. The distribution of subjects by professional category is as follows: $83.91 \%$ are nursing auxiliaries, $41 \%$ nurses and $2.68 \%$ nursing technicians.

The average time of work in nursing was 8 years, with a prevailing workload of 36 hours per week. It was evidenced that the manual of techniques or Standard Operating Procedure - SOP was available in the three studied hospitals. All participants reported knowledge of its existence in their work unit and considered compliance important.

The majority of participants (95.40\%) reported no difficulties in understanding, but several difficulties for using the manual, such as: lack of time, absence of some procedures, difficult understanding, not everyone complies with it, obsolete techniques, poor dissemination, difficult access, lack of material in the unit, disorganized manual, absence of indexes, extensive content, lack of figures or pictures, long time to review the manual, among others. Nonetheless, several benefits were also mentioned: allows correct performance of procedures, prevents errors, provides more safety to clients and employees, standardizes and updates techniques, clarifies doubts, controls expenses, diminishes the level of infections, saves nurses' time, assures good nursing care, among others.

The frequency of access to SOP by the nursing team during activities is presented in Figure 1. 


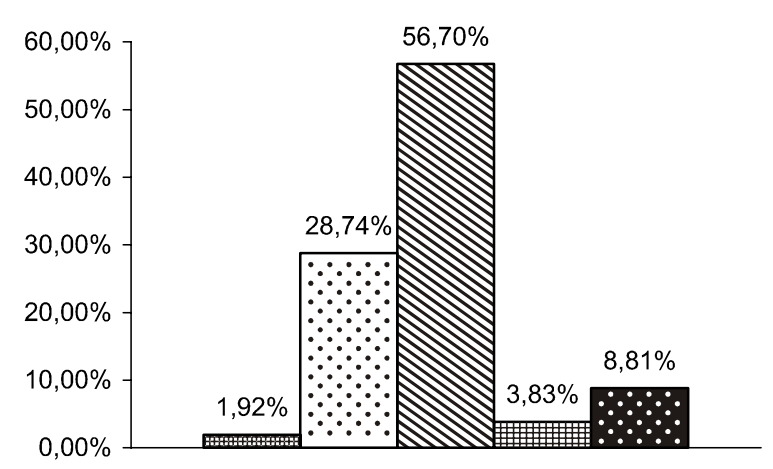

\section{田 Everyday}

๑ Only when I perform a technique that is not very common in the unit \$ Only when I have doubts

$\mathrm{TI}$ do not have the need because I already know all techniques

Others

Figure 1 - Relative frequency distribution according to nursing teams' access to SOP. São José do Rio Preto, SP, Brazil, 2007

In order to assure adequate standardization, all professionals should be involved. Thus, we verified how many believed the SOP was being complied with and it was found that $54.02 \%$ of nursing auxiliaries and technicians did not believe SOP was being followed by the whole team. In the nurse category, $62.86 \%$ reported they did not believe SOP was being followed by all nursing professionals, as showed in Figure 2.

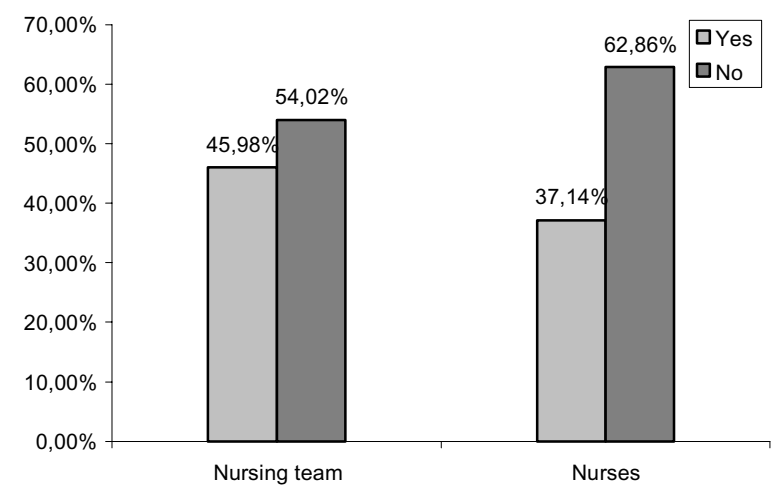

Figure 2 - Relative frequency distribution of the opinion of nurses, nursing technicians and auxiliaries regarding compliance with the SOP. São José do Rio Preto, SP, Brazil, 2007

The reasons most mentioned by those $(44.44 \%)$ who believed SOP was being followed by all nursing professionals were: need to clarify doubts, because it is standardized, it is mandatory or is the institution's norm, it is instructed and demanded by the nurse, because one depends on the manual to perform the correct technique and also because they observe people using it.

The reasons presented by the remaining $55.56 \%$, who did not believe the whole nursing team followed the manual, were: lack of time, the staff's reduced number and consequent work overload, lack of employees' interest, existence of habits of performing old and obsolete techniques, lack of awareness or understanding of the importance of standards, some "believe they know it all", because it is easier to ask another professional or a nurse to clarify doubts, due to lack of information or dissemination of SOP among employees, many SOP manuals or techniques are outdated, lack of encouragement or requirement by the service head, laziness, many learn the wrong way and keep doing things the wrong way, difficult access to SOP, many do what they consider easier and simpler and not what is correct, lack of specific training, lack of necessary material described in the SOP.

According to the subjects' observation regarding changes of nursing techniques in their sector, $75.86 \%$ of the sample reported they perceived some change and only $24.14 \%$ reported they did not notice any change. The average time of work in nursing for the latter group was five years. The most mentioned techniques that presented changes in their performance were: indwelling bladder catheterization (asepsis, closed system, passage mode, fixation, aid of other person), post-surgical bath, installation of central venous pressure, venous accesses (heparinization, dwelling time), nurses' private techniques (installation of chemotherapy drugs, nasoenteral/nasogastric catheter passage, blood gas collection), blood culture, installation of intraabdominal pressure, dressings (intracatheter- double lumen, used and humid product, use of gloves, barrier), caring for the umbilical stump (cleansing, open), medication administration and control of schedules, patient admission, evolution and discharge, use of swab (catheter disinfection), parenteral diet, use of equipment, material washing, hand washing, use of alcohol gel, mattress cleansing technique, contact-isolation precaution, service system (integral care), hemodialysis related procedures.

It was verified that the three studied hospitals review and update the SOPs, one of them through a specific committee, while the other two have it 
reviewed individually by nurses every six months, every year or when necessary. It was also verified that $55.75 \%$ of nursing auxiliaries and technicians believe reviews are necessary and $65.71 \%$ of nurses also report this need, as shown in Figure 3.

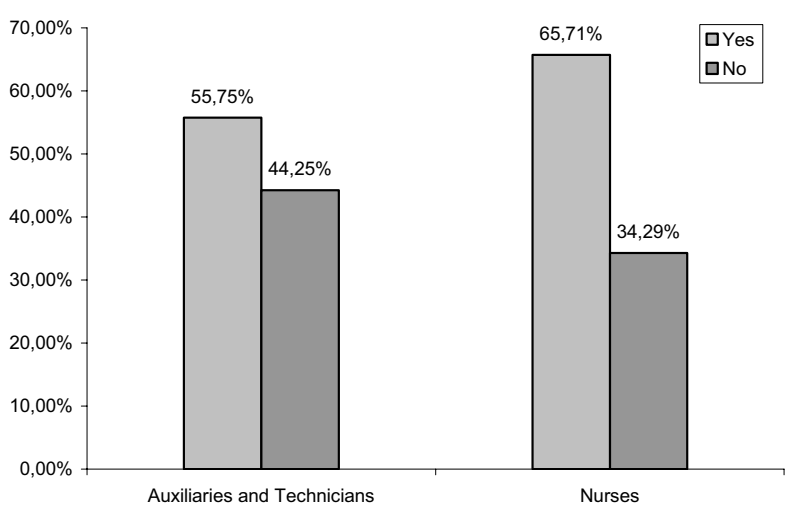

Figure 3 - Related frequency distribution of the opinion of nurses, nursing technicians and auxiliaries regarding the need to review the SOP. São José do Rio Preto, SP, Brazil, 2007

The main reasons appointed for reviewing SOPs were: to update techniques because of constant changes; some SOPs differ from the sector's reality, they should be specific for each unit; absence of some techniques, especially newly adopted techniques in the sector; to improve quality of care; due to outdated techniques or techniques that are no longer performed. Also, it should be clearer, simpler, use pictures or figures so as to encourage its use.

Regarding communication with the service head on the need to changing SOPs, $87.74 \%$ reported they never talked to their superiors regarding this need. It could be observed that most participants were somewhat afraid of proposing alterations and/or did not see the need to communicate it because there are specific professionals to appoint this need and they do not feel responsible for taking the initiative. The other $12.26 \%$ were asked how this communication had occurred, that is, what had been the result, and their answers were: changes are underway, SOP is under review, there was a meeting with no outcome, awaiting answers, no changes so far, positive result after agreement among all nurses.

\section{DISCUSSION}

There is predominance of nursing auxiliaries in this study, in line with the Brazilian reality. Estimates from the Federal Nursing Council of Brazil (COFEN) for the State of São Paulo until July 2007 indicate that $13.68 \%$ of nursing professionals were nurses, $9.94 \%$ nursing technicians and $76.38 \%$ nursing auxiliaries ${ }^{(13)}$.

Many participants revealed a certain concern and uncertainty when asked about compliance with the SOP by the whole nursing team. It should be stressed that the delivered care can be compromised in case the team is not united. Teamwork requires abilities to communicate, collaborate, understand each other and think with others. Thus, if the team has these abilities, it is possible to construct a common care project, different team members can organize their work, acknowledge the other's work and linkages ${ }^{(14)}$.

It is important to highlight that several actions mentioned by the nursing team can compromise adequate care delivered to the client and, consequently, the Nursing Code of Ethics, which states in its article 21, regarding responsibilities and duties: "Protect the person, family and community from harm due to inexperience, neglect or imprudence of any member of the Health Team"(15).

Thus, the real meaning of these concepts should be clearly stated: inexperience refers to lack of knowledge, technical training or ability to perform a certain procedure, that is, lack of experience, which can put patients at risk or cause them physical or psychological harm. Neglect is the same as disregard, carelessness, passiveness or omission, that is, one who can or must act in a certain way and does not due to idleness or laziness, either does not act or behave in the opposite way one is expected to. Imprudence stems from recklessness, lack of safety and forethought, which exposes patients to unnecessary risks and one does not attempt to minimize such risks ${ }^{(16)}$.

Therefore, it is essential that nursing professionals expose inadequate work conditions and are not collusive with professionals ${ }^{(16)}$ who engage in bad conduct. Also, as nurses are the leaders of nursing teams and are responsible for putting care in practice, they should be able to precisely and completely inform patients regarding procedures performed for them and with them ${ }^{(17)}$. Individual behavior and performance can directly affect the quality of services. Thus, each individual member of the team should clearly interpret the characteristics and influence of his(er) work to achieve quality ${ }^{(8)}$. 
It is important to keep in mind that changes in health organizations need evidence of effective scientific results, besides a positive cost-benefit relation. Therefore, "every organization simultaneously needs continuity and change, tradition and innovation, of being and becoming." ${ }^{\prime(18)}$.

Likewise, lack of knowledge is a component of work alienation. Thus, one should never forget that continuing education promotes personal and professional growth. It also supports change processes, the adoption of participative management, sharing of plans and decisions, the dissemination of knowledge and learning of new values ${ }^{(14)}$, and sensitizes people to their responsibility of selfdevelopment.

There is little research on nursing professionals' quality of work, although it could be observed in the analysis of changes in the quality of nursing care regarding some specific techniques that the characteristics of health facilities, work conditions, number of professionals, supervision and continuing education affect educational processes and, consequently, the quality of care ${ }^{(19)}$.

Additionally, no matter how technical a nursing activity may be, we can say that changes will always happen if we take into account its reflexive character. Knowledge will never cease re-creation and will indicate new alternatives of action, integrating knowledge to action ${ }^{(5)}$. One suggestion was to make SOP available on-line with free access for all health professionals from any unit. Thus, it would be possible to speed up its use and nursing care and also facilitate its update and review.

It should be reported that the "concept of quality should be incorporated in the institution's philosophy and also in the professionals' political will". Moreover, every institution that aims to attend the human being should be concerned with constant improvement of care, so that it can benefit from quality care constructed through three dimensions: structure (physical area, material resource, etc.), process (set of developed activities) and result (achievement of desirable characteristics) ${ }^{(14)}$

\section{REFERENCES}

1. Martins PG, Laugeni FP. Administração da produção. São Paulo: Saraiva; 1999.

2. Faraco MM, Albuquerque GL. Auditoria do método de assistência de enfermagem. Rev Bras Enferm. 2004;57(4):421-4.
The researchers also highlight that many professionals seem not to feel at ease to express their ideas. However, freedom is an inseparable partner of responsibility and implies that people have freedom to consider different situations they are presented with, analyze favorable or non-favorable aspects and make their own choice.

\section{CONCLUSION}

This study predominantly presented nursing auxiliaries $(83.91 \%)$, females $(76.63 \%)$, between 20 and 40 years old $(79.7 \%)$. It showed that SOP exists at the three studied institutions; $100 \%$ know about its existence in their work unit and consider compliance important; $95.4 \%$ have no difficulties understanding it, but report difficulties in using it due to lack of time, absence of some procedures, difficulty understanding, obsolete techniques, lack of required material.

It was verified that $56.7 \%$ access the SOP only when they have doubts; $54.02 \%$ of nursing technicians and auxiliaries and $62.86 \%$ of nurses do not believe the whole team complies with the SOP; $75.86 \%$ report they perceived changes in its techniques; its review and update are performed through a specific committee or individually by nurses and $55.75 \%$ of the nursing technicians and auxiliaries and $65.71 \%$ of nurses highlight the need for revision.

It is important to stress that, according to the study results, the SOP aims to clarify doubts. However, neither this process nor continuing education should be interrupted. Therefore, specific training on the SOP use is needed, with a view to a better understanding of the reasons why not all professionals follow standardized techniques. Automated performance of techniques is not desirable. On the contrary, knowledge combined with action is essential, even in situations considered simple. Therefore, professionals need to be engaged with care towards common results, to be involved with the institution's philosophy and to be able to cooperate and include the whole team, so that they can participate in the processes to improve care.

3. Nogueira LCL. Gerenciando pela qualidade total na saúde.

4. ed. Belo Horizonte (MG): Editora de Desenvolvimento Gerencial; 2003.

4. Antunes AV, Trevizan MA. Gerenciamento da qualidade: utilização no serviço de enfermagem. Rev Latino-am Enfermagem 2000;8(1):35-44. 
5. Schraiber LB, Peduzzi M, Sala A, Nemes MI, Castanhera ERL, Kon R. Planejamento, gestão e avaliação em saúde: identificando problemas. Ciênc Saúde Coletiva. $1999 ; 4(2): 221-42$.

6. Silva VEF. Manuais de enfermagem. In: Kurcgant P, coordenadora. Administração em enfermagem. São Paulo: Editora Pedagógica e Universitária; 1991. p. 59-72.

7. Magalhães AMM, Duarte ERM. Tendências gerenciais que podem levar a enfermagem a percorrer novos caminhos. Rev Bras Enferm. 2004;57(4):408-11.

8. Silva SH. Controle da qualidade assistencial de enfermagem: implementação de um modelo [Tese]. São Paulo (SP): Escola de Enfermagem de Ribeirão Preto/USP; 1994. 9. Andrade JS, Vieira MJ. Prática assistencial de enfermagem: problemas, perspectivas e necessidade de sistematização. Rev Bras Enferm. 2005;58(3):261-5.

10. Carpenito LJ. Diagnóstico de Enfermagem e Planejamento do Cuidado. In: Carpenito LJ. Diagnóstico de Enfermagem: aplicação à prática clínica. 8. ed. Porto Alegre: Artmed; 2002. p. 68-91.

11. Monte ADAS, Adami NP, Barros ALBL. Métodos avaliativos da assistência de enfermagem em instituições hospitalares. Acta Paul Enferm. 2001;14(1):89-97.]

12. Marconi MA, Lakatos EM. Metodologia científica. 5. ed. São Paulo(SP): Atlas; 2008
13. Conselho Federal de Enfermagem [Página na internet]. Rio de Janeiro: Conselho Federal de Enfermagem; [Acesso em 2007 julho 17] Canal de informações portal COFEN: registro de profissionais com inscrição definitiva válida em 2007. Disponível em: http://www.portalcofen.com.br 14. Kurcgant $P$, coordenadora. Gerenciamento em enfermagem. Rio de Janeiro: Guanabara Koogan; 2005.

15. Conselho Federal de Enfermagem [Página na internet]. Rio de Janeiro: Conselho Federal de Enfermagem; [Acesso em 2007 julho 05] Resolução Cofen no 311/2007 - Código de Ética dos profissionais de Enfermagem; [1 tela] Disponível em: http://corensp.org.br/072005/legislacoes/anexos/ resolucao-cofen-311-2007-codigo-etica.pdf

16. Freitas GF, Oguisso T. Ocorrências éticas na enfermagem. Rev Bras Enferm. 2003;56(6):637-9.

17. Trevizan MA, Mendes IAC, Lourenço MR, Shinyashiki GT. Aspectos éticos na ação gerencial do enfermeiro. Rev Latinoam Enfermagem. 2002;10(1):85-9.

18. Erdmann AL, Mello ALSF, Meirelles BHS, Marino SRA. As organizações de saúde na perspectiva da complexidade dos sistemas de cuidado. Rev Bras Enferm. 2004;57(4):46771.

19. Peduzzi M, Anselmi ML, França IJr, Santos CB. Qualidade no desempenho de técnicas dos trabalhadores de enfermagem de nível médio. Rev Saúde Pública. 2006;40(5):843-50. 